\title{
Advances In Multidiseciplinary

\section{An Optimized Web-Based Energy Billing System for Electricity Consumers in Nigeria}

\author{
Ebem, D.U. \& Okebanama, U.F. \\ ${ }^{1}$ Department of Computer Science \\ University of Nigeria, Nsukka \\ E-mail: deborah.ebem@unn.edu.ng, \\ Phone: +2348052810722
}

\begin{abstract}
Electricity consumers in Nigeria are faced with the challenge of inaccurate and delay in their monthly bills due to drawbacks in their billing systems. This paper presents the design and development of an optimized web-based energy billing system. The proposed system uses a smart meter to measure accurately the electric power consumed by customers in a user friendly manner. It is a web-based application developed with Object Oriented Analysis and Design (OOAD) methodology and implemented using C\# programming language with MySQL for back-end database. The meter measures and transmits consumed unit of a customer at the end of the month through a dedicated network. The system allows postpaid customers to clear their bills using recharge cards produced by the system administrator, while prepaid customers recharge their accounts before they have access to power and their consumption charges is deducted in real time. Customers can have access to their consumption history.
\end{abstract}

Keywords: Electricity, consumers, billing, meter, system, distribution.

Aims Research Journal Reference Format:

Ebem, D.E., Arinze, U, Ebem, C.C. \& Okebanama, U.F. (2018): An Optimized Web-Based Energy Billing System for Electricity Consumers in Nigeria. Advances in Multidisciplinary \& Scientific Research Journal. Vol. 4. No.3, Pp 53-64.

\section{INTRODUCTION}

Electricity power is one of the many requirements that encourage the growth of any country. With the steady increase in residential, commercial and industrial consumers of electricity all over the country, it has now become pertinent for distribution companies to figure out better ways of measuring the consumption of electricity so that correct bills can be generated (K.P Satheagamoorthy 2013. p 3845).

Usually, the electricity meters are installed on customer's buildings and the consumption information is collated by meter readers on their monthly visits to the premises. This manner of measuring electricity consumption is inefficient, because a meter- reader or personnel of an electricity company has to physically be on-site to take the readings. This method of collating reading becomes more problematic and costly and has the following limitations (i) lack of integrity and credibility of meter readers and (ii) Unavailability of customers at the time of need. (iii) The propensity of bill estimation as a guide to the likely consumption for the current month. (A. Adegboyega 2013, P.45). This tends to generate inefficient billing for both consumers and the electricity distribution companies and might lead to wrong billing. In most cases the consumer may not have utilized comparable amount of electricity at the current month as in the previous months for reasons such as, engagements that took him/her outside his/her home for awhile or the user has actually used more than the assumed bill, and so on. Sending him a bill for a larger amount or a meager amount compared to what he/she actually consumed in a month is not transparent enough and may result to billing error. 


\section{Advances In Multidiseciplinary

The Electricity distribution company of Nigeria has been exploring series of innovations for its present metering system. Such innovations include Automatic Meter Reading (AMR) and the Pre-payment Meter Scheme (A.Al-omery and W. Elmedany 2011, p. 35). These new ideas are targeted to reducing theft and other forms of avoidable losses in the system. The pre-payment meter which has been recently introduced in some parts of Nigeria uses Smart Card in dispensing energy. The stress of purchasing the smart card only from the Utility Company; and lack of feedback mechanism after recharging is a major setbacks.

This research provides an excellent solution to the challenges mentioned above where the system will be designed based on a simulation of the use of smart meter to automatically read electrical energy consumed by a customer. The energy meter reading is sent to the control center in the electricity department based on an enabled full duplex communication as provided in the simulation.

It focuses on offering consumers the opportunity for applying for new service connection/reconnection, terminating a connection and paying energy charges using energy recharge cards. It can disconnect a household if the household refrains or delays in paying the required bill. The system has high accuracy and reliability in that it keeps adequate records of customer's payments. Its calculation reflects the exact power consumption for customers and maintains an accurate history of customer's payment and offers total paperless transaction both for the energy users and the utility company.

\subsection{Objectives of the Study}

The specific objectives of this study are to:

- $\quad$ Generate accurate bills corresponding to energy consumed.

- Keep adequate records of customers bills and payments

- Connect and disconnect energy customers remotely

- $\quad$ Easy the process of bill payment by introducing the use of smart energy recharge cards

- $\quad$ Give customers the ability to access their payment history.

- Provide statistical reports to distribution companies that assist in their planning

\section{REVIEW OF RELATED WORKS}

A critical review of the computerization stages which Nigeria energy sector has undergone while trying to address its problem of bill distribution, reveals two notable stages namely: Manual and prepaid billing system. Even so, there are studies which project the smart billing system. These systems are examined in the literature review given below.

\subsection{Manual Billing System}

In the manual system, human labor plays an important role in taking note of customer's consumed unit and its management. In this system, employees from the electricity service provider visit customer's home once in a month, take the meter readings and submit to their billing offices (M.Babu and M.Antony 2016, p. 1048). The electricity board officer generates bills by these meter readings. The accuracy of this system is most times not reliable. The system has no consistent means of keeping customer's records and this allows poor access to billing records.

Also, research carried out in (L. Abdulwahab 2009, p. 27) revealed that $38 \%$ of the analogue meters that assist in this manual system were installed between eleven to twenty-one years ago. The study equally revealed that poor and unreliable power supply and often the bills issued by electricity service providers are based on estimates, thus contributing to poor consumer's response to payments of electricity bills. This system is inaccurate, costly and slow and lacks flexibility as well as reliability.

\subsection{Estimated Billing System.}

In the Nigeria electricity distribution companies, some of the consumers are unmetered. This circumstance has continued despite efforts by the Nigerian Electricity Regulatory Commission (NERC) to reduce the gap in recent years (C.C Ofonyelu and R.E Ejiofor). The problem of billing out-of-the meter gave room for estimated billing which was often against the electricity consumers. The main setback with billing by estimate had been the propensity to overcharge electricity users and provoke payment apathy (L.Abdulwahab 2009, p. 28). This type of electricity billing is termed asymmetry billing pattern. 
Asymmetry in electricity billing refers to arbitraries and lack of transparency in the process of assessing and costing of consumers' units consumed. In Nigeria, the common form of arbitrariness in Electricity Distribution Company of Nigeria (EDCN) billing includes charging of electricity rate outside the approved tariff, irregularity in metering and estimated billing (F. Asu 2016). Under asymmetric billing pattern, consumers are faced with estimated bill, which does not depend on actual energy consumed. In the bill, the charged amount of energy consumed remains same for all customers under the same classification within a district, town or state. This is true irrespective of the variation in actual amount of electricity consumed by the persons concerned or the size of the buildings/household.

According to F. Asu (2016) electricity consumers alleged that distribution companies decided not to supply meters and uses estimated billing system as an avenue to extort energy consumers even when they do not enjoy constant power supply. Furthermore, energy consumers while condemning the system of estimated billings adopted by distribution companies said their pay do not reflect their consumption per month.

\subsection{Prepaid Billing System}

The incessant disagreement of customers and poor response to payment of electricity bills in Nigeria led to the introduction of prepaid billing system. However, there have been problems that have risen from this innovation. Though, researchers within and outside Nigeria have been working to improve this system. According to (N.T Makanjuola, O.Shoewo 2015, p.22) the present prepaid billing pattern in Nigeria is a well-established technology being introduced by many utility companies. It is a system where a customer pays for energy before using it but with numerous disadvantages ranging from: difficulty on tariff charge change, poor customer record keeping and difficulty in recharging the meter most times. Researchers have further designed systems to improve this existing system. In J.S. Prajapati and A,P. Patel (2014, p. 441) a system that uses Global System for Mobile (GSM) communication an optical fibre for transmitting customers consumed unit was proposed. This system is based on prepaid platform but it has no means of keeping the adequate record of customers and their payment history.

The author in(K.Jubi, J. Mareena, 2013, p.2048) emphasized on the use of prepaid energy meter using GSM technology. This system relied on the use of recharge cards as a means of recharging the prepaid meter for a period; it equally has no means of further documentation of customers' information. The GSM communication module is used to send customers consumed units and their balance and also a Liquid Crystal Display (LCD) is used to display the balance amount. According to S.Raikar and S.S Majigoudar (2014, p. 912) a prepaid billing system that uses adaptive meter is proposed. In the proposed system, the front end is user-friendly and the billing process is prepaid. It is designed in such a way that recharging could be done remotely without accessing the energy meter physically. This system can improve on the existing prepaid billing pattern but does not consider keeping of customers records.

The work in (A.Jain and M.Bagree 2011 p. 160) designed a smart power billing system using a prepaid meter that has similarities with prepaid mobile phones. A prepaid card is contained by the meter just like a mobile phone. In this scenario, the prepaid card communicates directly with the power utility using mobile technology. If the prepaid card is out of balance, the customer is disconnected from the utility supply. The prepaid card can be recharged remotely using mobile communication based on customer request; this system was implemented with mat lab software for simulation. It has no consideration for proper record keeping. In (A.O Oyubu etel 2015, p. 35) a system that makes use of two GSM modems each with a dedicated Subscriber Identity Module (SIM) card. One of the SIM is integrated with the system and the consumer's energy meter while the second SIM is linked with the personal computer housing the customer's database at the office of the energy company. A two-way communication is achieved in the system by installing sets of AT (Attention) control strings in both GSM modems. According to S.Ganuikar and P.Gour (2014, p. 12) the use of a prepaid billing system was proposed. This system uses a keypad on the meter to recharge. This system pays no attention to record keeping. Its primary role is just to ensure that customers pay before they consume.

In (M.D Mejbaul 2011, p. 592) a single phase digital prepaid energy meter was proposed based on two microcontrollers and a single phase energy meter. This digital prepaid meter is not exactly like the conventional prepaid meter because it has no rotating part. The customers consumed unit is calculated using the output pulses of the energy meter chip and the internal of the microcontroller. A microcontroller is used as the smart card and the number of units recharged by the customer is written in it. But changing of the tariff is not remote or automation and recharging it is complicated most times. 


\subsection{Smart Meter Based Billing Systems}

Smart meter billing system is the most recent power measuring device that is presently in use in most countries of the world. Different authors continued to propose new methods of improving the existing systems. In (K.P Satheagamoorthy 2013. p 3845) a system that can automatically send the consumed unit by a customer digitally to the billing office with the assistance of the GSM modem once in a day, the system equally generates a report and sends to the service provider once in a day through SMS. This system can be used to check the last units consumed by a consumer, with the demand request sent by the user through the same method. It can also be used to control the load appliances from both ends with the assistance of a relay circuit. The customers consumed units are displayed using Liquid Crystal Display (LCD) Customer tariff control became an issue in this system and also poor record keeping.

An improved system was developed by (N.N Jinde 2013, p. 425) which have the ability to send the consumed unit. The proposed model includes an office module which has a Personal Computer (PC) with its back end linked to a database. The other module is the customer's home module which is present at the consumer's home. This module is used to take records of the amount of power consumed by the customer. In J.Zhang and C.L Bai (2008, p.34) a Digital Signal Processing (DSP) based meter was used to measure the electricity consumption of multiple users in a residential area. A Personal Computer (PC) was used at the control centre to send commands to a remote meter, which in turn transmitted consumed units back, using the power Line Communication (PLC) technique. The major problem with this system is that it cannot detect tampering by consumers.

An online web application that reduces human errors that are often associated with the manual billing processes is proposed in (G.E Pataki 2003, p. 20). A prototype of online smart electricity tracking the system using GSM was developed. In this system the administrator can analyze the customer's power consumption and generate a report from the data online. In this system customers only have access to their bills. There is no further recording keeping after customer's bills have been cleared. A system that incorporates the use of smart energy meter was proposed in (S.V Vanmore and P.Avalekar 2016, p. 121). This system provides the ability to use both prepaid and postpaid mode. In this system, a microcontroller was used for selecting prepaid and postpaid mode. In the prepaid mode, balance can be recharged by the end user as he requires and in the postpaid, monthly bills are sent by post to the end user. This system does not consider record keeping as criteria for good power management. In B.S Kaoy (2003, p. 67) the researchers designed and implemented a system using Bluetooth energy meter where some meters which are nearby, communicated wirelessly with a master PC. Distance coverage is a major setback for this kind of system because Bluetooth technology only performs better at proximity.

M.H Shwehdi and C. Jackson (1998, p.41) Presented a digital tale-wattmeter system as an instance of a microcontroller based meter. This meter was implemented to transmit data on a monthly basis to a remote central office through a devoted telephone line and a pair of modems. It is a standalone metering system and does not consider customer detailed records. A computerized automatic meter reading system was developed in (G. Rachitha, and R. Kumar et al 2010 , p.106 ). The proposed system work perfectly with the following: accurate digital meter, a transmission facility and the billing server. This system uses General Packet Radio Service (GPRS) technology provided by GSM networks. It only sends customer bills to them and they make payments in their distribution offices or in the bank. A system that can transmit customer's bill to the billing office was proposed in (G.Rachitha and R. Kumar 2010, p. 106). This system can monitor the consumed unit of a customer without visiting the premises. It uses GSM facilities to transmit to the billing office; these bills got processed and sent to the customers via SMS. It has no facility of keeping customer's payment detail. This system did not consider keeping customers records.

However, in L.C Jingwen and T.V. Liu (2008, p. 42) a remote real-time automatic meter reading system was proposed. This system employs distributed structure in line with wireless sensor networks, which consists of sensor nodes, measure meters, data collectors, wireless communication network and servers. This system is more interested in measuring customer's bills. A system that uses a camera to capture customers consumed unit was proposed in (M. Babul and Mccra Antony. 2011, p87) . The camera is fixed in front of the meter to take snapshots. The captured image processed and the consumed units extracted. The bill amount is calculated and is sent to the customer as SMS via GSM module. The consumed unit is later sent to the billing office for documentation purpose. MAT lab enabled software is used to extract the number from the camera and store it as a variable. The meter's previous month's reading is subtracted from the present month's reading for accurate billing. The difference thus obtained is multiplied by the tariff and converted into electricity bill. The system keeps records of its present reading for calculating next month's readings based on the method. 


\section{Advances In Multidiseiplinary

The reviewed system above is cumbersome and expensive to implement. According to S. Rastogi and M. Sharma (2016, p. 13) a smart meter captures power unit consumed by a customer at every given time, displays results and consequently transmits it to the power billing unit.

\subsection{Research Gaps in Literature: The Way Forward}

After a thorough review of related works, no work has explored a smart meter interfacing with a web based billing system. In this proposed system, a novel approach is designed. A unique method to clearing customer's bills is introduced, this approach considered the use of recharge cards which will be sold by local vendors for clearing bills. The data sent to the billing system are not just for billing and payment alone but most other purposes. Some of these purposes include but not limited to the following:

- $\quad$ Enumerate the income rate of a distribution phase

- $\quad$ Determine the distribution phase that is patronized more.

- Monitor income

- $\quad$ Bill details are sent to customers profiles

- $\quad$ Adequate customers record keeping is achieved

- $\quad$ Easy payment of both prepaid and postpaid bills using EDCN recharge cards

- $\quad$ Provide administrative support to monitor customers payments

\section{RESEARCH METHODOLOGY}

Object oriented analysis and design (OOAD) methodology and universal modeling language (UML) were employed in this work. The block diagram of the proposed system is given below. The diagram shows the principal parts or functions in blocks and connected by arrows to show their relationship

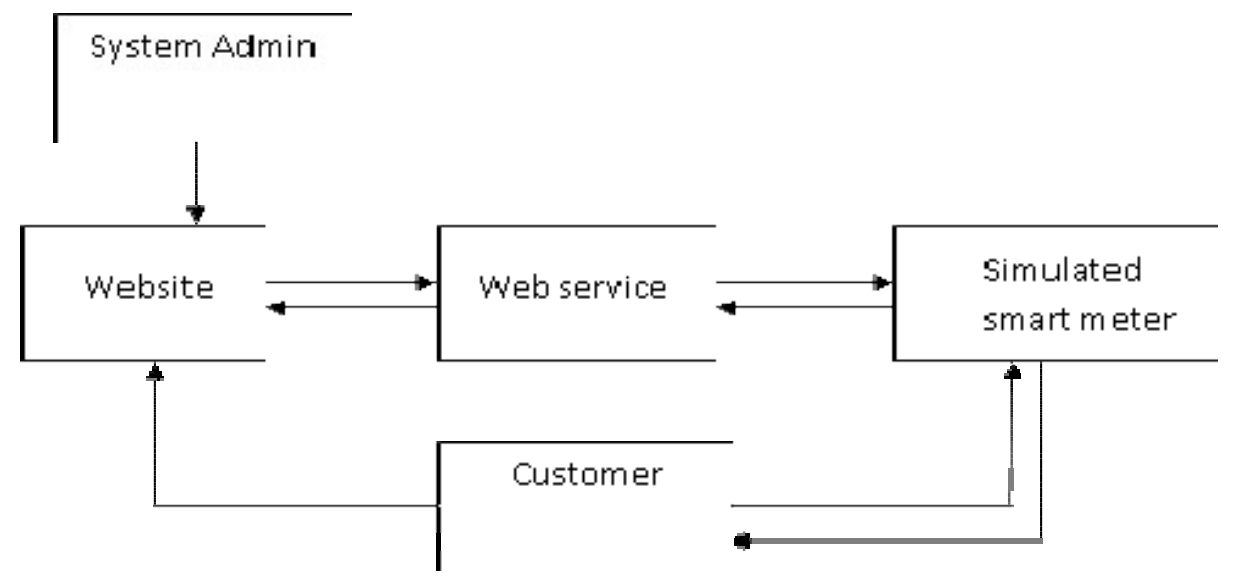

Figure 1 Block diagram of the proposed system

The research was carried out using a smart metering system that has the ability to transmit customers consumed unit to the billing station through a dedicated network. The system considered two types of customers which are prepaid customer and postpaid customers. A recharge voucher was introduced for the purpose of clearing and recharging accounts. Prepayment customers which are basically household customers pre-recharge their account before they can have access to power; their deduction is done in real time which reflects their exact consumed unit. While postpaid customers are basically business establishment and industrial customers, their bill is sent to their account at the end of the month. The postpaid customers have the ability to clear their bill using recharge cards. If the charge is not cleared at the stipulated time the customer will be disconnected remotely and be reconnected as soon as his outstanding bill is cleared. The administration of the website is handled by an authorized Electricity Distribution company of Nigeria staff in order to handle customer service activities. A formal model of the proposed system is presented in activity diagrams. These models will provide a conceptual view and provides graphical analysis of the customer and the administrator. 


\section{Advances In Multidisciplinary}

Res \& Scientifie Research

Vol. 4 No. 3, September 2018

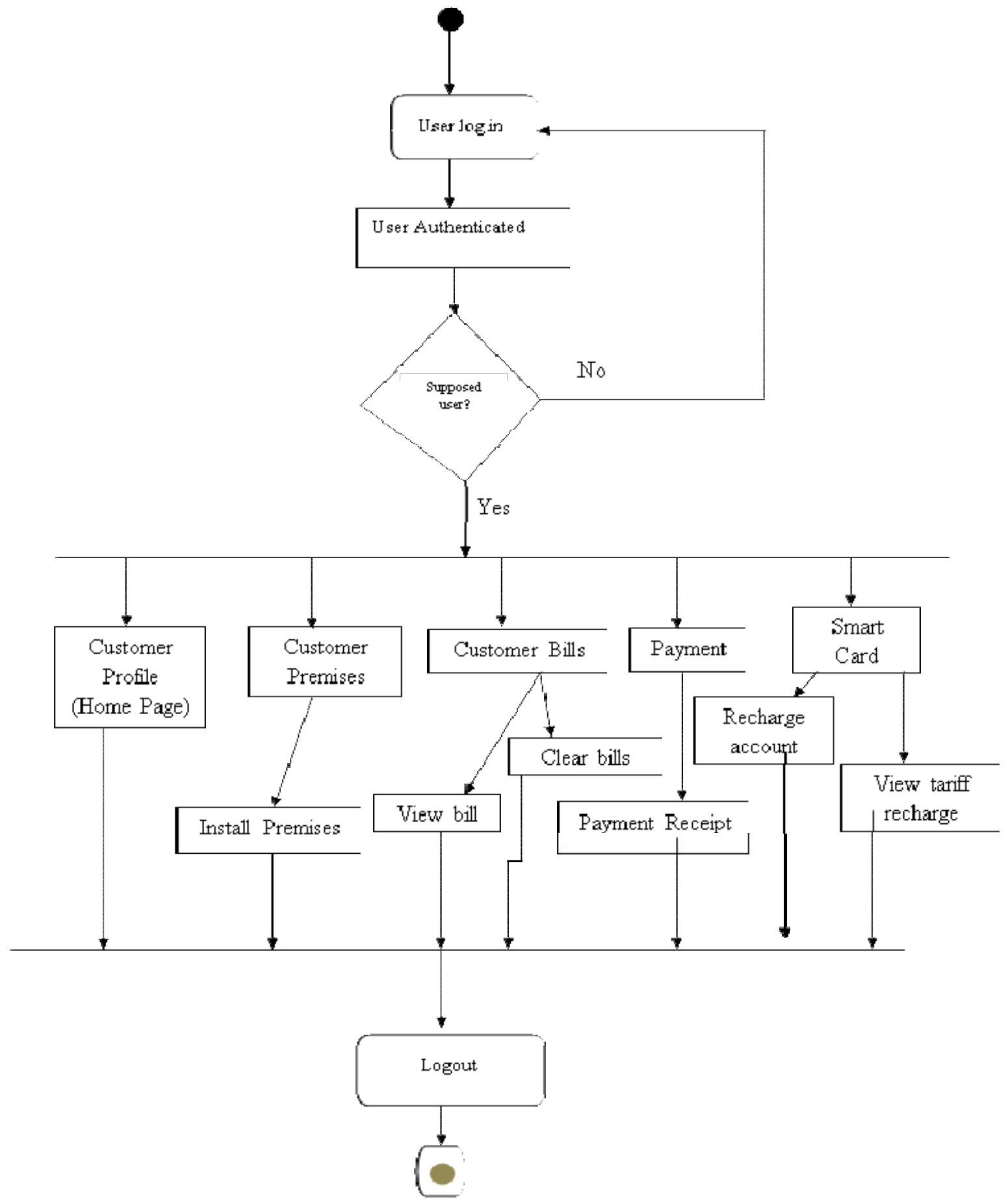

Figure 2 Customer activity diagram 
Advances In Multidiseiplinary A. Pis \& Scientifie Research

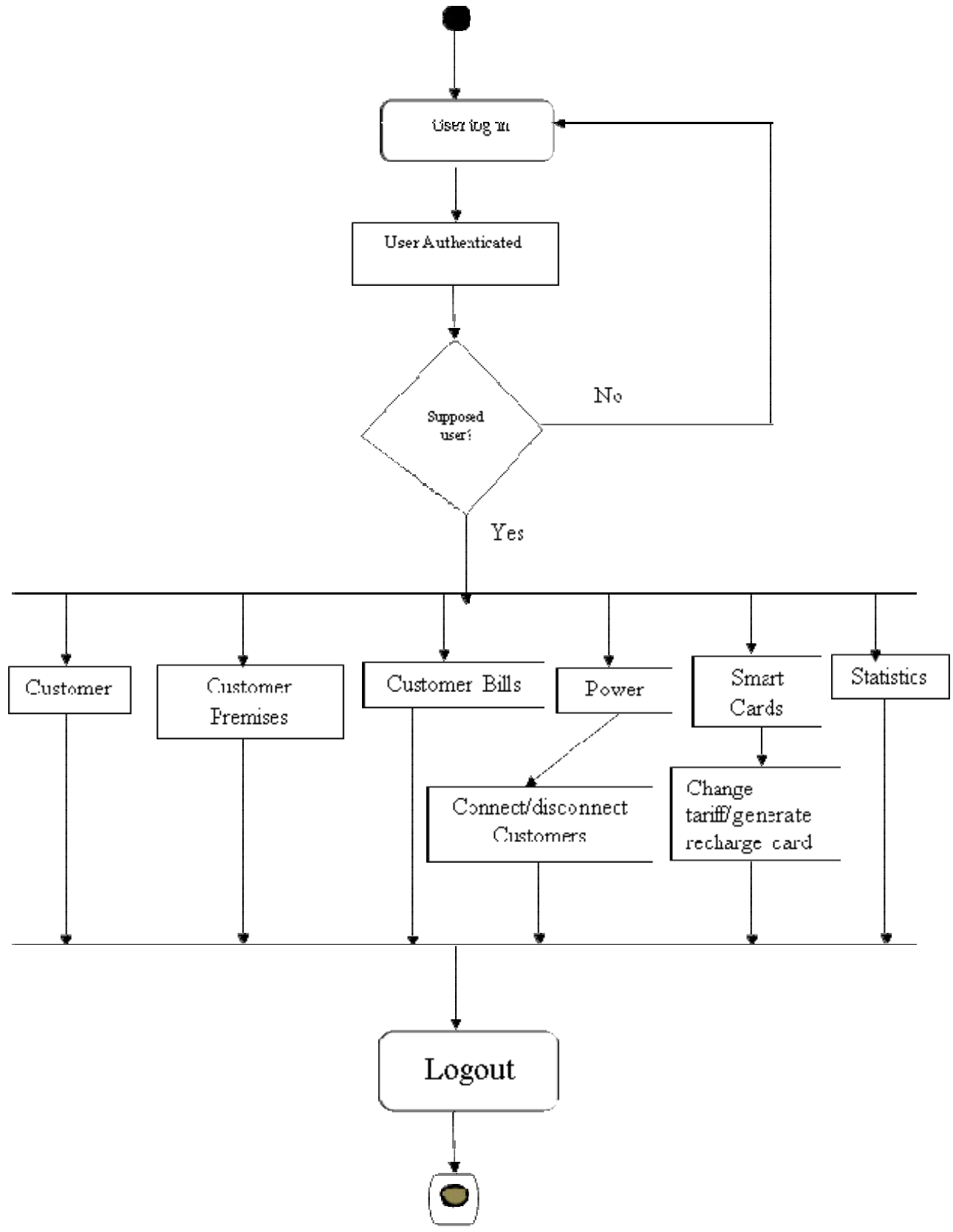

Figure 3: Activity diagram for Administrator 


\section{Advances In Multidisciplinary

\subsection{Algorithms}

This shows the step-by- step set of operations that takes place at the simulated smart meter end and how bills are calculated.

1. Start

2. Authenticate Customer

3. Set Arbitrary customer $=$ Authenticated Customer

4. Select Customer premises of Arbitrary customer

5. Set load $=$ Customer premises load

6. Set Meter Reading $=0$

7. Set Meter Reading $=$ Meter reading $+(\operatorname{load} / 60 * 60)$

8. Read Meter Status

9. Repeat step 6,7 until Meter Status = "Due"

10. Upload Meter Reading

11. Read choice

12. Repeat step $5,6,7,8,9,10$ until choice = "Add load" or "Remove load" or "Exit"

13. If choice $=$ "Add load" Then

Read new load

Set load = load + new load

Goto step6

14. If choice $="$ Remove load" Then

Select Remove load

Set load $=$ load - Remove load

Goto step6

15. If choice $=$ "Exit" Then

Goto 15

16. END

Algorithm 3.0.1: Simulated smart meter algorithm

1. Start

2. Authenticate customer

3. Read Meter Reading, Tariff, Consumption History, DueDate

4. Set charge $=$ meter Reading ${ }^{*}$ Tariff

5. Set Bill = Charge, Meter Reading, Tariff, consumption History, Duedate

6. Insert to Database bill Table

7. Read choice

8. Repeat step 2,3,4,5,6,7 until choice = "Exit"

9. END.

Algorithm 3.0.2: Customer billing algorithm at the smart meter end.

\section{RESULT}

The implementation was done using C\# programming language with SQL support for backend application. The system captures almost all information about a customer ranging from getting new connection and disconnections. The system starts by displaying the homepage. Thereafter, a customer using the system for the first time creates an account where he fills in his required details. The system then prompts a log in page for such customer and the admin has a log in form too. The system validates the user name and passwords. A customer when logged into the system has the ability to do the following: install his premises and choose if the premises installed are household, industrial and business establishment. Household customers strictly run on prepayment billing while business establishment and industrial customers run on postpaid billing with administrative conditions. The administrator has the ability to do the following: issue power control commands, view customer/ customer premises, connect and disconnect customers. The simulated smart meter has the ability to send and receive information from the website through a web communication foundation. 


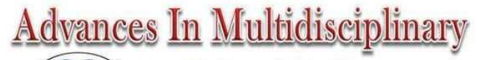

\section{EDCN billings poRtal( CUStomer ACCOUnt Sign In )}

\section{HOME ADMINISTRATIONS CUSTOMER SERVICES ABOUT US

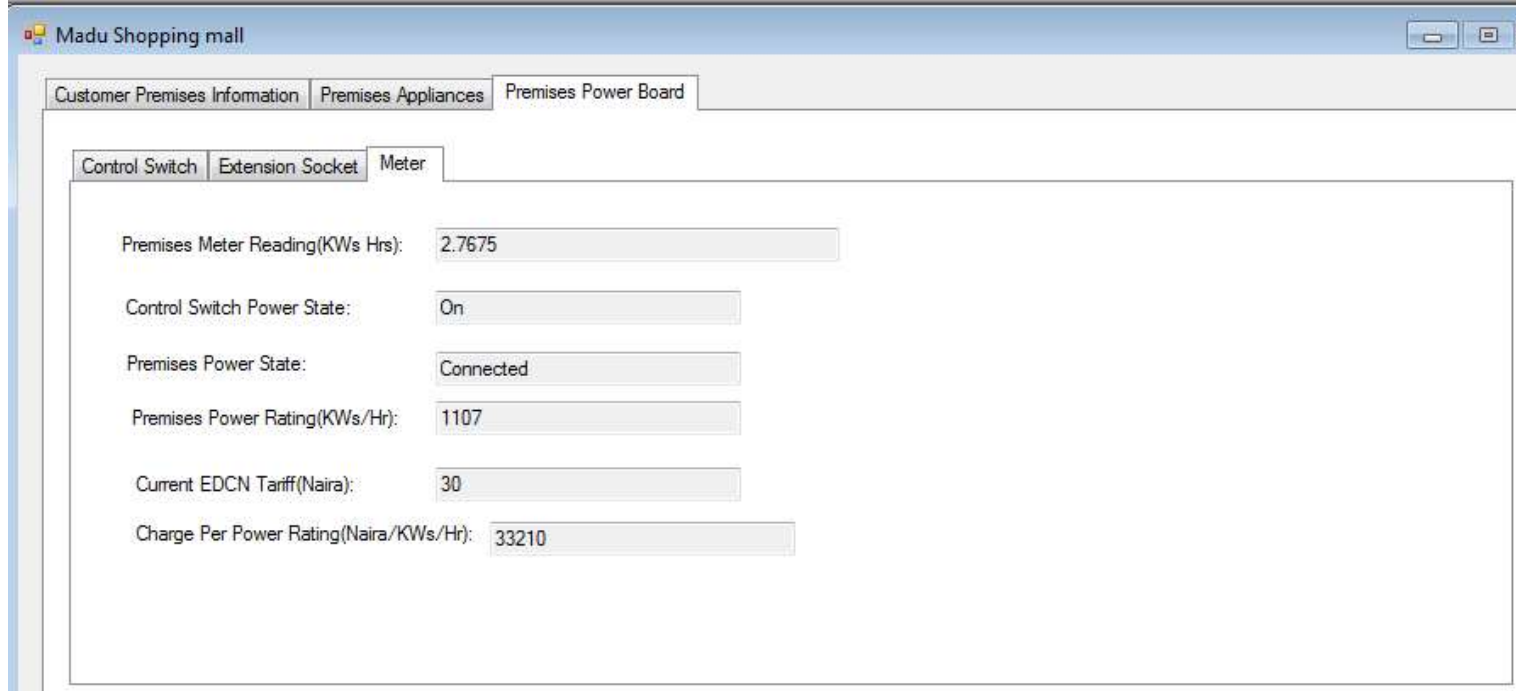

Figure 5: Simulated meter page for customers 


\section{Advances In Multédisciplinary

Table 1: Customer payment history

\begin{tabular}{|c|c|c|c|c|c|c|c|}
\hline \multicolumn{8}{|c|}{ Enter Key Words } \\
\hline $\begin{array}{l}\text { Source } \\
\text { Customer } \\
\text { Premises }\end{array}$ & Payment ID & Bill ID & $\begin{array}{c}\text { Power } \\
\text { Consumption } \\
\text { Charge }\end{array}$ & $\begin{array}{c}\text { Bill Due } \\
\text { Date/Period }\end{array}$ & $\begin{array}{l}\text { Bill } \\
\text { Tariff } \\
\text { Mode }\end{array}$ & $\begin{array}{c}\text { Payment } \\
\text { Date/Period }\end{array}$ & Action \\
\hline $\begin{array}{l}\text { Madu } \\
\text { Shopping } \\
\text { mall }\end{array}$ & 18446514189966939917 & 19146514189966939917 & 876.375 & $\begin{array}{l}\text { 01-Feb-17 } \\
3: 35: 17 \text { PM }\end{array}$ & Postpaid & $\begin{array}{l}\text { Wednesday, } \\
\text { March 01, } \\
2017\end{array}$ & Print Payment Slip \\
\hline $\begin{array}{l}\text { Madu } \\
\text { Shopping } \\
\text { mall }\end{array}$ & 18567914084124969351 & 19267914084124969351 & 470.475 & $\begin{array}{l}\text { 01-Mar-17 } \\
3: 36: 14 \text { PM }\end{array}$ & Postpaid & $\begin{array}{l}\text { Wednesday, } \\
\text { March 01, } \\
2017\end{array}$ & Print Payment Slip \\
\hline $\begin{array}{l}\text { Madu } \\
\text { Shopping } \\
\text { mall }\end{array}$ & 18604368679358420476 & 19304368679358420476 & 590.4 & $\begin{array}{l}\text { 01-Apr-17 } \\
3: 45: 36 \text { PM }\end{array}$ & Postpaid & $\begin{array}{l}\text { Monday, May } \\
01,2017\end{array}$ & Print Payment Slip \\
\hline $\begin{array}{l}\text { Madu } \\
\text { Shopping } \\
\text { mall }\end{array}$ & 18725882643659034624 & 19425882643659034624 & 295.2 & $\begin{array}{l}\text { 01-May-17 } \\
3: 46: 12 \text { PM }\end{array}$ & Postpaid & $\begin{array}{l}\text { Monday, May } \\
01,2017\end{array}$ & Print Payment Slip \\
\hline $\begin{array}{l}\text { Madu } \\
\text { Residential } \\
\text { house }\end{array}$ & 18824285828323329033 & 19540173966658603766 & 3.9217 & $\begin{array}{l}\text { 01-May-17 } \\
3: 47: 44 \text { PM }\end{array}$ & Prepaid & $\begin{array}{l}\text { Monday, May } \\
01,2017\end{array}$ & Print Payment Slip \\
\hline $\begin{array}{l}\text { Madu } \\
\text { Residential } \\
\text { house }\end{array}$ & 18988342641442591267 & 19617726499806012607 & 509.8167 & $\begin{array}{l}\text { 01-Jun-17 } \\
3: 51: 33 \text { PM }\end{array}$ & Prepaid & $\begin{array}{l}\text { Thursday, } \\
\text { June 01, } 2017\end{array}$ & Print Payment Slip \\
\hline
\end{tabular}

Table 2: Admin view of all customers

\begin{tabular}{|c|c|c|c|c|c|c|c|}
\hline \multicolumn{2}{|l|}{ Enter Key Words } & \multicolumn{6}{|c|}{ Search Keywords } \\
\hline Customer Reg. IDs & Customer Name & Sex & Email & Phone & Address & No. of Installed Premises & No. of Uncleared Bills \\
\hline 20043686793584204764 & Cletus Okeke & Male & cletus@gmail.com & 08088072687 & ezenweze street & 3 premises installations & None \\
\hline 22465141899669399179 & CLIFF OKEKE & Male & cliff123@gmail.com & 09087789623 & opi & None & None \\
\hline 23465141899669399179 & Franklin Okebanama & Male & frankmarvin92@gmail.com & 08066988896 & Cartwright Street UNN & 4 premises installations & None \\
\hline 25186481099136925789 & Madu Wilson & Male & madu@gmail.co & 08143198214 & Opi road Nsukka & 3 premises installations & 1 bills \\
\hline 24465141899669399179 & Ryan Okebanama & Male & ryan@gmail.com & 08143198213 & Opi road Nsukka & 3 premises installations & None \\
\hline 21242858283233290331 & Uchenna Junior & Male & uche@gmail.com & 07066788196 & Opi Road Nsukka & 3 premises installations & 1 bills \\
\hline
\end{tabular}

\section{DISCUSSION}

The system is developed in a way that the smart meter transits consumed unit to the billing station through a communication channel that synchronizes with the web service. Customers account can be recharged at the website using recharge voucher produced by the system administrator. This recharged voucher can be used by both a prepaid customer and a postpaid customer. For a prepaid customer who is strictly a household customer, his bill is deducted in real time from his account while a postpaid customer can clear his bill at the end of the month using the same recharge voucher at the end of the month and can be disconnected if he does not meet up with the administrative conditions. A customer has the ability to install new premises, view his bills; clear them, have access to his billing records and make complaints. The administrator of the system controls the entire operation of the system. He has the ability to view all customers/ customer premises, connect and disconnect customers, view bill details and have clear financial details of the entire operation. 


\section{Advances In Multidiseciplinary

The web based system is so detailed that it keeps total track of customer's details, smart disconnection and reconnection of a customer. Any postpaid customer who fails to pay his bill gets disconnected and is required to pay bill interest for allowing him to get disconnected before reconnection takes place.

\section{CONCLUSION}

A novel approach for energy billing using smart meter has been designed and implemented. The smart recharge protocol for clearing outstanding and pre-recharging bill has been developed and the overall idea has been simulated too. The recharge concept and billing transparency of the proposed system has been tested and the results obtained show good performance. It is observed that the consumed energy by a customer is directly proportional to the amount of energy recharge unit purchased by a customer. This shows that the proposed system is reliable, efficient and dependable. If fully implemented by Electricity Distribution Companies of Nigeria, proper accountability will be obtained and the rate of patronage will increase since customers can enjoy billing transparency and also clear their bills, pre-recharge their accounts within the comfort of their houses without the stress of visiting the distribution stations for activation.

\section{REFERENCES}

1. K.P Satheagamoorthy 2013 "Smart Energy Meterloadcontrol," International Journal of Advanced Research in Electrical, Electronics and Instrumentation Engineering.Vol.2 Issue 8. Pp 3845-3851 .

2. A. Adegboyega,Ayeni .A. Gabriel et al 2013 "Design and Implementation Of an Enhance Power Billing System for Electricity Consumers in Nigeria", African Journal of Computing\&ICT"Vol.6 Issue1 pp49-58,

3. Alauddin Al-Omary, Wael El-Medany et al 2011 "Design and Implementation of Secure Low Cost AMR system using GPRS Technology", International Conference on Telecommunication Technology and Applications vol 8. Issue 1 pp 35-42.

4. M. Babu, M. Antony et al 2016“Automatic Electricity Billing"International Journal of Advanced Research in Computer and Communication Engineering Vol.5 Issue 3. Pp 1048-1051 .

5. L. Abdulwahab. 2009 "An Assessment of Billing Electricity Consumers via Analogue Meters in Kano, Nigeria" Bayero Journal of Pure and Applied Sciences Vol. 2. Issue 1 pp 27-33.

6. C. C Ofonyelu, R. E. Eguabor ( "Metered and Unmetered Billing: How Asymmetric Are The Phcn Bills?" .

7. F. Asu 2016 'Crazy bills:No respite for Nigerian Electricity Consumers".www.punchnewspapers.com. Published December 31, 2016.

8. N.T. Makanjuola, O. Shoewu 2015 "Investigating the Problems of Prepaid Metering Systems in Nigeria" International Journal of Advanced Research in Electrical, Electronics and Instrumentation Engineering Vol5. Issue2 pp 22-31

9. J. S. Prajapati, A.P. Patel "Prepaid Electricity Billing System" Journal Of Information, Knowledge and Research In Electronics and Communication Engineering Vol 2. Issue 2. Pp 441- 443.

10. K. Jubi, J. Mareena 2013 "Prepaid Energy Meter with GSM Technology" American International Journal of Research in Science, Technology, Engineering \& MathematicsVol 3. Issue 3 pp 2048- 2054 .

11. S. Raikar, S.S. Majigoudar 2014 "Prepaid Power Billing Using Adaptive Meter" International Journal of Advanced Research in Electrical, Electronics and Instrumentation Engineering,Vol 3.Issue Issue 6. Pp 99129920.

12. A. Jain, M.Bagree 2011 "A prepaid metermobile communication using", International Journal of Engineering, Science and Technology, Vol. 3,Issue 3 pp 160-166.

13. A. O.Oyubu, C. A.Nwabueze 2015 "Design And Testing Of A Smart Energy Metering System Based On Gsm Modem" European journal of engineering and technology. Vol 3. Issue $4 \mathrm{pp} 35-42$

14. S. Ganurkar, P. Gour 2014 "Prepaid Energy Meter for Billing System Using Microcontroller and Recharge Card"International Journal Of Core Engineering \& Management, Vol1. Issue 1 pp 12-18.

15. M .D. Mejbaul 2011 "Microcontroller Based Single Phase Digital Prepaid Energy Meter for Improved Metering" International Journal of Power Electronics and Drive System, Vol 4.Issue 3 pp 592- 598.

16. Namita, N. Jinde, et al 2013 "Powerline Communication Based on Energy Meter Automation "International Journal of Electronics Communication and Computer Engineeringvol3 Issue 5 pp9425-9432 [Online].

17. J Zhang, C.LBai. 2008 "DSP based electricity meter with remote reading" proceedings of the 4th InternationalConference on Signal Processing" Vol2 Issue 3 pp34-39.

18. G.E. Pataki, 2003 “A Primer On Smart Metering”, New York State Energy Research And DevelopmentAuthority. 
19. S.V. Vanmore, P. Avalekar et al 2016 "Prepaid and Postpaid Energy Meter for Billing System Using Microcontroller and GSM" International Research Journal of Engineering and Technology, Vol 3, Issue 2 pp 1214-1216.

20. B.S Kaoy 2003 "Design and implementation of Bluetooth energy meter"Proceedings of the joint 4th international conference on Information, communication and signal processing and the $4^{\text {th }}$ Pacific Rim conference on multimediavol 3, Issue 3 pp 67-73

21. M.H Shwehdi, C Jackson 1998 "A microprocessor based digital wattmeter system design"proceedings of the $31^{\text {st }}$ Intersociety Conference on Energy Conversion Engineeringieeexplore.ieee.orgAccessed on April 2, 2017

22. A. Al-Omary,W. El-Medanyet et al 2011“Design and Implementation of Secure Low Cost AMR system using GPRS Technology" International Conference on Telecommunication Technology and Applications vol 7 Issue 1 pp35-42

23. G. Rachitha, R. Kumar et al 2010 "GSM Based Energy Meter and Billing via Sms" International Journal of Latest Research in Engineering and Technology, in procRDFCORDGE - 2014 pp 106-110

24. L.C.Jingwen, T.Y.Liu, 2008 " Remote Real Time Automatic Meter Reading System Based on Wireless Sensor Networks", 3rd International Conference on Innovative Computing Information and Control vol6/ssue 8 pg42-51 citeseerx.ist.psu.edu .

25. M. Babu1, Meera Antony et al 2016“Automatic Electricity Billing” International Journal of Advanced Research in Computer and Communication Engineering ,Vol.5 Issue 3. Pp 1048-1051.

26. S. Rastogi, M. Sharma et al 2016 "Internet of Things based Smart Electricity Meters" International Journal of Computer Applications, Vol. 133 Issue 8 pp 13-16 Jan. 2016 